\title{
EU R\&D Funding as a Way of Incentivizing Innovation of SMEs: A Review of Impacts
}

\section{Nevenka Čučković}

Institute for Development and International Relations,

Zagreb, Croatia

nena@irmo.hr

\section{Valentina Vučković}

University of Zagreb, Faculty of Economics and Business, Zagreb, Croatia

vvuckovic@efzg.hr
CroEconSur

Vol. 20

No. 2

December 2018

pp. $97-127$

Received: February 16, 2018

Accepted: October 29, 2018

Review Article

doi:10.15179/ces.20.2.4

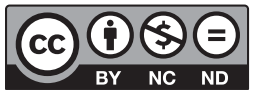

\section{Abstract}

The Innovation Union flagship initiative, with its accompanying policies and actions, strives to ensure stronger involvement of SMEs in EU R\&I programs. The main idea behind this paper is to review and discuss the impacts of SMEs' participation in EU R\&D programs as a way of boosting their innovation activities. The paper addresses several research questions that help us to present the effects of increased availability of EU R\&D funding on boosting innovation activities of SMEs across EU. We start by examining the current innovation performance of EU SMEs based on selected descriptive statistics and indicators. After that, we turn to elaborating the empirical and theoretical foundations and rationale for increased public funding through the EU R\&D programs targeting SMEs. Then we discuss the impact of FP7, CIP, Eurostars, and Horizon 2020 
funding on SME recipients. We briefly survey the results of available empirical studies that use both quantitative and qualitative evidence, and examine their outcomes in terms of direct and indirect impacts on innovation activities in EU member state SMEs. The examined empirical evidence points to several positive effects of participating in EU R\&D programs on incentivizing innovation activities, output, and performance of recipient SMEs.

Keywords: SMEs, innovation, R\&D, competitiveness, EU R\&D funding

JEL classification: $\mathrm{O} 31, \mathrm{O} 38, \mathrm{O} 52$

\section{Introduction}

In order to speed up the recovery of the European economy after the 2008 economic crisis, $R \& D$, innovation, and knowledge creation capacity started to be seen as crucial productivity sources, especially at the level of small and medium enterprises (SMEs). SMEs represent a pulsing part of all EU economies, particularly as they are the dominant type of enterprise (on average accounting for 99 percent of the enterprise sector), but also in terms of their participation in total value added (58 percent) and employment ( 67 percent). They are also the most dynamic and vibrant part of the enterprise sector in terms of start-ups and new jobs. An important share of total innovation activities are taking place in SMEs, as many of them were established or have significantly scaled-up their businesses on the basis of new products or services.

Relying more on SMEs to increase innovative products, services, and processes, but also to create new jobs through fast-growing SMEs, has thus become an integral part of the EU 2020 strategy (European Commission, 2010a) and its flagship initiative Innovation Union (European Commission, 2010b). Both strategic documents emphasize the task of ensuring a stronger involvement of SMEs in future R\&I programs in the EU, especially within the Horizon 2020 program that was launched to overcome the fragmentation of previous EU 
R\&D funding programs. This task became one of the 34 commitments of the Innovation Union to be fulfilled in EU member states by 2020. The economic rationale behind this commitment is to ensure an integrated EU funding scheme tailored to the specific R\&D and innovation needs of SMEs to limit market failure in access to finance, as SMEs are in a more fragile position than larger enterprises due to their size and limited financial capabilities. The empirical evidence so far points to significant positive effects of participating in EU funding schemes on the innovation performance of SMEs. ${ }^{1}$

The contribution of the paper is threefold. First, we explore data and empirical evidence that provide deeper insights and understanding of what sort of impacts EU R\&D funds have on boosting research and innovation in the EU SME sector. ${ }^{2}$ We mostly review previous empirical evidence on direct impacts of EU funding on innovation activities, investments, and output in SMEs. ${ }^{3}$ By innovation activities in SMEs we consider all new and creative products (goods and services), as well as processes with significant technological, organizational, or marketing novelty, which is in line with Eurostat's definition. The second contribution is in examining the role and direct impacts of the integrated financial support programs and instruments for SMEs within Horizon 2020 on R\&I investments and innovation output. Last but not least, the text aims to contribute to discussions on methodological issues pertinent to assessing the effect of public intervention on innovation performances of SMEs.

The paper is structured as follows. After the Introduction, Section 2 analyzes the current innovation performance of EU SMEs based on selected descriptive statistics and innovation performance indicators. Section 3 deals with the theoretical rationale for supporting innovation activities in SMEs through public funding, and presents empirical evidence on previous EU funding programs

1 For a good overview, see Becker (2015). For detailed evidence on the impacts of Horizon 2020 funding on SMEs, see European Commission (2017a, 2017b, 2017c, 2017f).

2 This paper is based on the research done by the authors for the H2020 project "Investigating the Impact of the Innovation Union - I3U”, financed by the European Commission (Grant Agreement No. 645884).

3 We would like to thank the two anonymous reviewers for their valuable comments, insights, and suggestions that assisted us in preparing the final version of this text. 
(FP7, CIP, Eurostars). Section 4 discusses the role of Horizon 2020. Finally, Section 5 summarizes the findings and presents policy implications.

\section{European SMEs and Recent Innovation Performance}

According to the latest European Innovation Scoreboard (European Commission, 2018), when it comes to innovation performance, SMEs share the general trend of innovation activities in the EU (Figure 1). Although the overall performance of the EU innovation system increased by 2.0 percentage points in the 2010 2017 period, performance across specific dimensions and indicators differs significantly.

Figure 1: EU SME Innovation Performance, Change between 2014 and 2017

SMEs introducing product or process innovations as \% of SMEs

SMEs introducing marketing or organizational innovations as \% of SMEs

SMEs innovating in-house as \% of SMEs

Innovative SMEs collaborating with others (\% of SMEs)

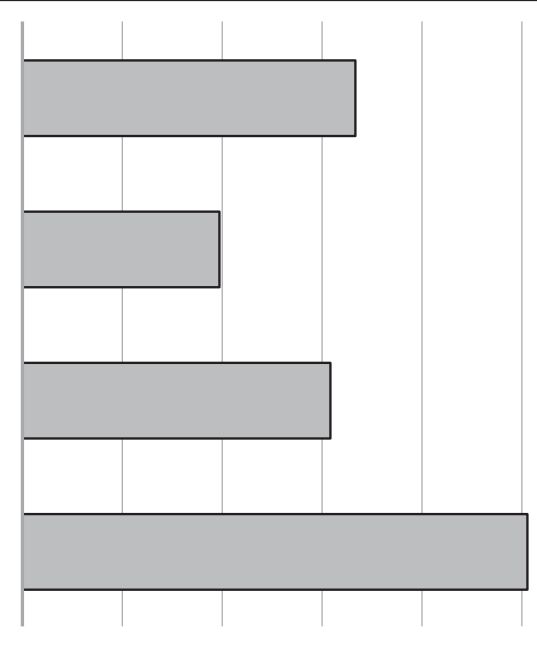

85

$90 \quad 95$

100

110

Source: Authors' compilation based on the European Innovation Scoreboard 2018 database. 
As for the SME innovation performance indicators, which are in the focus of our attention when discussing the impacts of $\mathrm{H} 2020$ funding, the data show that the share of SMEs innovating in-house increased by 0.5 percentage points compared to 2014. At the same time, innovators in SMEs produced 1.6 percentage points more products/process innovations, but 5 percentage points less marketing and organizational innovations in 2017 compared to 2014. On the other hand, the cooperation of innovative SMEs with others increased in the 2010-2016 period by 10.3 percentage points.

In general, the positive role of SMEs in innovation and economic development has been widely evidenced so far: besides contributing to GDP and employment growth, they are also seen as important innovation drivers and conduits for knowledge spillovers, especially when it comes to fast-growing SMEs. Apart from in-house innovations, SMEs' innovative activities are also clustered around and implemented through their tight collaboration with larger companies, as well as with various research organizations and higher-education institutions. A number of empirical studies have documented that GDP and employment growth effects are generated through the process of innovation in which SMEs play several important roles (see OECD, 2010; Keizer, Dijkstra, \& Halman, 2002; Stam \& Wennberg, 2009; Love \& Roper, 2015). Firstly, new firm creation and SME growth increase productivity and bring new or underutilized resources into use. Secondly, new spin-off ventures enable the commercialization of knowledge, and finally, SMEs participate in knowledge flows within the innovation system (see OECD, 2010).

Specifically, SMEs contribute greatly to innovation activities and output by introducing new or significantly improved products and services, processes, organizational methods, and/or marketing techniques. This is precisely how innovation activities in enterprises are defined and measured by Eurostat innovation statistics and we follow suit. ${ }^{4}$

4 The Community Innovation Survey (CIS) defines innovation activities in enterprises as "new or significantly improved goods or services, and the introduction of new or significantly improved processes, logistics or distribution methods". For more information, see Eurostat, CIS Innovation Statistics Explained. 
The specific types of innovation activities in EU SMEs are presented in Table 1.

Table 1: Innovation Activities of EU SMEs, 2012, 2014, and 2016, \% of Enterprises

\begin{tabular}{|c|c|c|c|c|c|c|}
\hline & $\begin{array}{l}\text { Product } \\
\text { and/or } \\
\text { process } \\
\text { innovative } \\
\text { enterprises }\end{array}$ & $\begin{array}{c}\text { Organization } \\
\text { and/or } \\
\text { marketing } \\
\text { innovative } \\
\text { enterprises }\end{array}$ & $\begin{array}{c}\text { Product } \\
\text { and/or } \\
\text { process } \\
\text { innovative } \\
\text { enterprises }\end{array}$ & $\begin{array}{c}\text { Organization } \\
\text { and/or } \\
\text { marketing } \\
\text { innovative } \\
\text { enterprises }\end{array}$ & $\begin{array}{c}\text { Product } \\
\text { and/or } \\
\text { process } \\
\text { innovative } \\
\text { enterprises }\end{array}$ & $\begin{array}{c}\text { Organization } \\
\text { and/or } \\
\text { marketing } \\
\text { innovative } \\
\text { enterprises }\end{array}$ \\
\hline & 2012 & 2012 & 2014 & 2014 & 2016 & 2016 \\
\hline EU-28 & 30.6 & 36.2 & 30.9 & 34.9 & 34.2 & 36.5 \\
\hline
\end{tabular}

Sources: Eurostat, CIS 2012, CIS 2014, and Provisional CIS 2016 data.

Table 1 reveals that among innovating SMEs (in 2012, 2014, and 2016), those with marketing or organizational innovations slightly predominate compared to product or process innovating EU enterprises. However, provisional CIS 2016 data show a more significant growth of product and/or process innovation SMEs (from 30.6 percent in 2012 to 34.2 percent in 2016) than organizational and marketing innovation SMEs (from 36.2 percent in 2012 to 36.5 percent in 2016). Another positive development, based on provisional CIS 2016 data for 21 member states, is that the share of sales due to new-to-market and new-to-firm product innovations is estimated to have increased from 13.4 in 2014 to 13.7 percent in 2016.

Since the share of innovative SMEs in the total number of EU enterprises is naturally much larger than the share of large enterprises (SMEs represent about 99 percent of enterprises), in order to avoid bias in interpretation, we look into the share of enterprises by specific type of innovation, i.e., product and process innovation (taking into consideration the firm size) (Figure 2).

Although large EU enterprises (those over 250 employees) are still dominant across all types of innovation activities ${ }^{5}$, Figure 2 confirms that along with the large enterprises, SMEs (particularly medium sized) are significant potential 5 On average, according to Eurostat innovation statistics, they were more likely to have introduced innovations than SMEs, as almost 8 in 10 (78.1 percent) large enterprises in the EU-28 were innovative during the 2012-2014 period (Eurostat, Innovation Statistics, 2017). 
innovation players in the EU, with their focus slightly more on product than process innovations ${ }^{6}$.

Figure 2: Enterprises by Size and Specific Type of Innovation, in \%

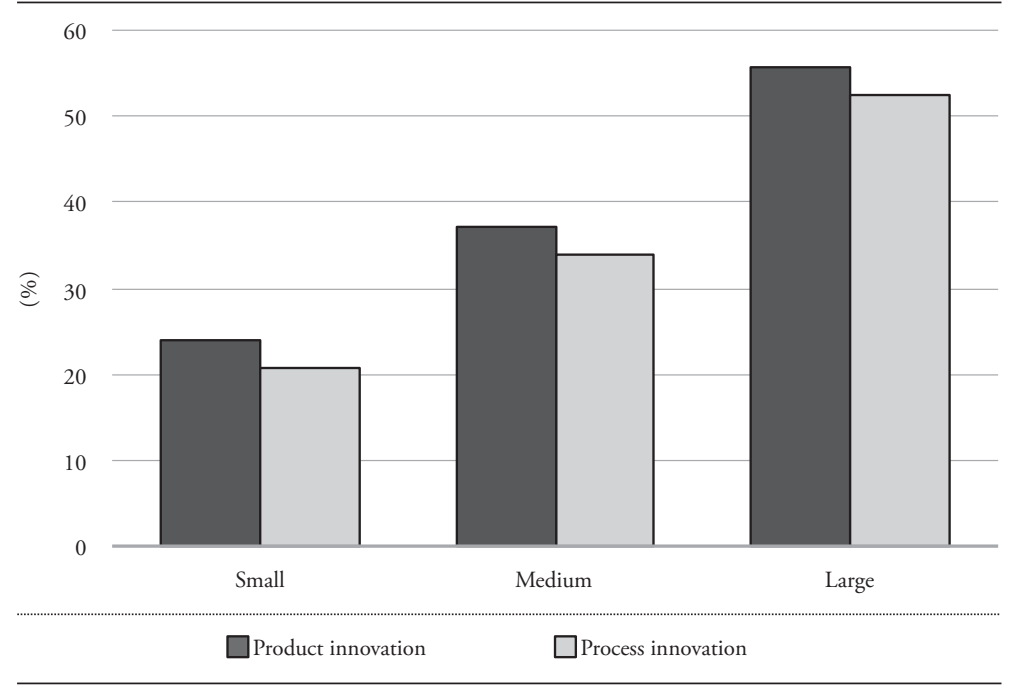

Source: Authors' calculation based on CIS data (Eurostat, CIS 2014).

The empirical literature proves that these two types of innovations have very distinct impacts on sectoral employment and economic performance. While the impact of product innovations is usually positive, the impact of process innovation is small or negative (see Hall, 2011; Peters et al., 2014; Damijan, Kostevc, \& Stare, 2014). Due to such results, we put more weight on product innovation in this paper too. Product innovation is seen as the introduction of a good or service that is new or significantly improved with respect to its characteristics or intended uses. This includes significant improvements in technical specifications, components and materials, incorporated software, user friendliness, or other functional characteristics. Further, process innovation is defined as the implementation of a new or significantly improved production or

6 Data for EU-15. 
delivery method, which includes significant changes in techniques, equipment, and/or software. Process innovations thus enhance total factor productivity, while product innovations modify the quality of products.

The innovation output of SMEs is often traditionally measured by their participation in patent applications as a proxy of their innovation outcome, despite the fact that this is only their intermediate output. Although the share of SMEs in total innovation output is still much smaller than the share of large enterprises, which account for nearly four-fifths of total innovation output measured by patent applications, the growth trend of the SME share is promising. However, the data for the SME share in EU patents are still not easily available, and analysts rely mainly on the survey conducted for Eurostat. The first step in obtaining reliable indicators of the SME share of EU corporate patenting consists of matching firms' patent data to financial data.

A survey conducted for Eurostat (Eurostat, 2014) that combined automated matching to financial directories with additional searches gives us more precise estimators of the SME share of patent activity. For the EU as a whole, the 2014 survey found that 79 percent of all patent technology can be attributed to large firms and 17 percent to SMEs. For 4 percent, the size of the corporate applicant remains unclear. At the same time, SME contribution varies considerably across member states. Additional analysis (Section 3 of the survey) focusing on SMEs' contribution in different areas of technology identifies the comparative advantages for the 16 technologically most active member states.

The results indicate a distinctive contribution from SMEs in a considerable number of technological fields. By using multiple regression analysis per field of technology, SME specialization patterns (RTAs) were correlated to overall national specialization patterns. In 21 of the 35 fields of technology, there is a significant correlation between SME specialization and national specialization. While this SME contribution to national specialization patterns is (in the majority of fields) complemented by large firms' contribution as well, specialization 
seems to be spearheaded by SMEs in a number of emerging fields, including environmental technology, analysis of biological materials, and micro-structure and nano-technology. These findings underline the intertwining of SME and large-firm technological development in the EU's industrial landscape.

However, important insights from previous empirical research ${ }^{7}$, including the Eurostat 2014 survey, point to the conclusion that young and fast-growing SMEs, due to their flexibility, contribute relatively more to "radical" or "breakthrough" innovations in comparison to large firms. The Horizon 2020 dedicated SME financial support instrument is exactly targeting SMEs' ability to produce and commercialize breakthrough innovations to enable the EU economy to advance and better cope with world competitors.

Finally, the main issue is not whether firm size is conductive to innovation, but which market characteristics favor large, and which favor small firms (Veugelers, 2008). As already mentioned, the main disadvantage for SMEs is found in access to finance. Moreover, Peters et al. (2014) point out that credit constraints represent a substantial problem for the funding of innovation projects especially in smaller and younger firms, while large firms have larger internal means to finance those activities. Thus, public funding could be particularly effective in increasing innovation investments in SMEs that are more financially constrained. Thus, in the following section we examine the role of public funding of SME innovation, and what has actually changed after the launch of the Innovation Union in 2010 and introduction of various financial support programs and instruments offered for SMEs within Horizon 2020.

7 See, for instance, studies based on extensive surveys of SME funding recipients, such as European Commission (2017e, 2017f, 2017g). 


\section{Public Funding of SME Innovation: Theoretical Rationale and Empirical Evidence}

\subsection{Theoretical Rationale for Public Funding}

In the previous section, we highlighted the significant role that SMEs play in EU innovation activities and output. But, what actually qualifies SMEs for increased EU public funding and what are the reasons that would justify such an intervention? One of the crucial components for the success of any innovation process is access to finance, i.e., ensuring adequate financial resources for innovation investments (Hall \& Lerner, 2010; Afcha, 2012). This particularly relates to the success of innovation activities in SMEs as they have very limited internal resources that could be dedicated to innovation, and thus they are much more dependent on external funding than larger enterprises. Such a situation produces relative and comparative disadvantages for SMEs and a higher price of capital than for larger competitors (Canepa \& Stoneman, 2008). Therefore, to limit market failure in access to finance, they particularly need a "helping hand" from public funds such as the EU R\&D programs, which could serve as an impetus for growth of innovation activities in such enterprises (OECD, 2010; Radas, Anic, Tafro, \& Wagner, 2015). Additionally, public support could also ensure improved access to equity and venture funding, and facilitate faster internationalization of SMEs (European Commission, 2011). However, according to Wessner (2008), although venture capital firms (along with industry and universities) provide funding for early stage technology development, there is also a significant role of the government, which addresses the segments of the innovation cycle that private investors often do not fund because they find it too risky or too small.

Mazzucato (2013, p. 43) highlights that "the state's role is not just to create knowledge through national labs and universities, but also to mobilize resources that allow knowledge and innovations to diffuse broadly across sectors of the economy", introducing the term of entrepreneurial state. However, David, Hall, and Toole (2000) argue that this type of funding should not be by any means 
perceived as a substitute, but rather a complement to private $R \& D$ funding that could lead to more innovations, especially in smaller enterprises. Like some other authors (Guellec \& von Pottelsberghe, 2003; Duguet, 2006), they also warn that there might be a "crowding-out" effect of such type of funding. Depending on subsidy rates, this funding might lead not towards an increase, but to a decrease of efficiency of innovation investments if the funding substitutes the firms' own investment and goes to an increase of $R \& D$ personnel wages instead.

Public funding (at national or EU level) plays a significant role in funding new technologies (such as ICT and others), thus enabling greater technological innovations, but also channeling and spreading the benefits of them directly to the society. Innovation is also important for developing solutions to growing economic and social challenges such as climate change, aging population, rising poverty and inequality, energy efficiency, and others. The situation is also the same in the US, Japan, and other EU main competitors such as BRICs (Rodrik, 2015), and the EU is presently lagging behind when it comes to developing fastgrowing SMEs that could address these challenges appropriately and even become global leaders in finding solutions (European Commission, 2011). Therefore, the innovative process requires significant and appropriate public policy support to secure the wider social benefits it can deliver. Wessner (2008, p. 52) highlights that "...governments around the world view the development and transformation of their innovation systems as an important way to promote the competitiveness of national industries and services... and that they are increasingly inspired by the achieved results of US Small Business Innovation Research (SBIR) type of funding program.” The same report (Wessner, 2008) shows that such programs result in various benefits (economic and noneconomic), as small companies use them to advance projects, develop firm-specific capabilities, and ultimately create and market new commercial products and services. In addition, SBIR has yielded a variety of knowledge outputs such as patents and licenses of patents, prototype products and processes, spin-off companies, and new "human capital" that have enhanced know-how, expertise, and sharing of knowledge. 
Figure 3: Enterprises Having Received Public Funding for Innovation Activities, CIS 2012 vs CIS 2014, in \%
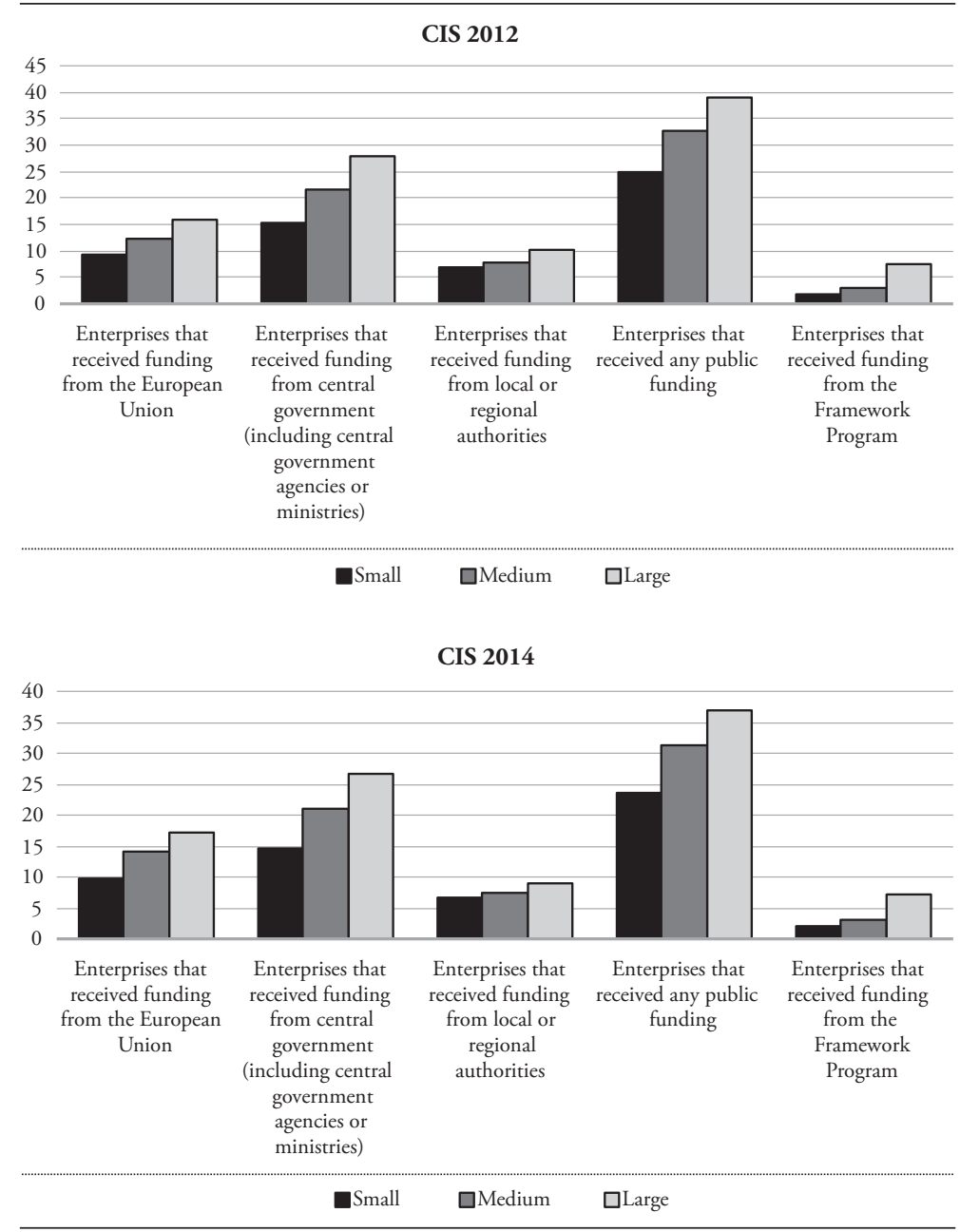

Source: Authors' calculation based on CIS data (Eurostat, CIS 2012 and CIS 2014).

EU R\&D funding programs such as FP7 and Horizon 2020 have also acknowledged such an economic rationale. At the EU level, SMEs have been included in projects that provide them with valuable financial assistance in 
stimulating research, innovation, and creativity. Data in Figure 3 show the share of small, medium, and large enterprises from the aspect of specific funds, i.e., the share of enterprises that have received funding from the $7^{\text {th }}$ Framework Program and from the European Union. The data show that these funds represent a significant source of finance for innovative SMEs.

CIS 2012 and 2014 data in Figure 3 show that (on average for the EU) large innovative firms are more likely to receive public funding than SMEs (regardless of the type of funds).

If we analyze the change in the share of firms that received funding in CIS 2014 compared to CIS 2012 (Table 2), we can conclude that in general the share of firms (in each size group) that received funding from the EU decreased. Provisional CIS 2016 data indicate that this trend might change, but detailed data are not available yet.

Table 2: Public Funding in the Enterprises by Size, 2014/2012 Change

\begin{tabular}{l|c|c|c|c|c}
\hline Size & $\begin{array}{c}\text { Enterprises } \\
\text { that received } \\
\text { funding } \\
\text { from the } \\
\text { European } \\
\text { Union }\end{array}$ & $\begin{array}{c}\text { Enterprises that } \\
\text { received funding from } \\
\text { central government } \\
\text { (including central } \\
\text { government agencies or } \\
\text { ministries) }\end{array}$ & $\begin{array}{c}\text { Enterprises } \\
\text { that received } \\
\text { funding } \\
\text { from local } \\
\text { or regional } \\
\text { authorities }\end{array}$ & $\begin{array}{c}\text { Enterprises } \\
\text { that } \\
\text { received } \\
\text { any public } \\
\text { funding }\end{array}$ & $\begin{array}{c}\text { Enterprises } \\
\text { that received } \\
\text { funding } \\
\text { from the 7th } \\
\text { Framework } \\
\text { Program }\end{array}$ \\
\hline Small & 95.3 & 104.0 & 104.8 & 106.2 & 91.6 \\
\hline Medium & 87.5 & 102.9 & 106.0 & 104.3 & 99.7 \\
\hline Large & 91.4 & 104.7 & 111.5 & 105.8 & 102.6 \\
\hline
\end{tabular}

Source: Authors' calculation based on CIS data (Eurostat, CIS 2012 and CIS 2014).

\subsection{The Impact of the R\&D Funding Programs on SMEs: A Review of Selected Empirical Research}

Direct financial support to enterprises with the goal of enhancing innovation activities is one of the most prevalent innovation support measures in industrialized countries. Concretely, public funding of innovation projects aims to assist firms to do materially more development work than would be the case 
otherwise, producing more innovation (in turn resulting in increased sales/profits for assisted businesses, increased productivity gains, etc.).

When analyzing the position of SMEs in previous European Research and Innovation Programs, a detailed study by the European Parliament (2013) describes the level of participation of SMEs in FP7, CIP, and Eurostars. The data show that the highest EU contribution in funding provided for SMEs under FP7 comes from the Cooperation program. The main type of projects in the program are Collaborative Projects (CP), which focus on research, but also include other activities, such as management and training. SMEs that participate in CP come from a number of industrial sectors. The largest share of SMEs (28 percent) in the Cooperation program are from the R\&D sector, while 25 percent of them are from the manufacturing sector, 18 percent from the ICT sector, 24 percent from the services sector, and 4 percent are consultancy firms. However, as Barajas, Huergo, and Moreno (2011) highlight, the Cooperation research scheme supports European SMEs with a specific research objective but without (or with limited) technological capacity, which implies that a large proportion of the technological development will be done by the R\&D performers included in the consortia. ${ }^{8}$ Compared to the Cooperation program ${ }^{9}$, the specific support schemes of the Capacity program attract to a much higher extent firms from the manufacturing industry (41 percent), while a much lower (21 percent) share of firms come from the R\&D sector. Further, although much smaller than FP7, the CIP Eco-Innovation program is an example of an innovation instrument that is highly attractive for SMEs as the funding comes in the form of grants, the main advantage of which is that they are faster than collaborative projects. Within CIP, 137 highly innovative SMEs benefited from financial instruments/venture capital until 2013, with 18 percent of them belonging to the eco-innovation sector. Finally, apart from FP7 and the schemes provided in CIP, the Eurostars program aims to support European R\&D-performing SMEs. The unique feature

8 In such a case, SMEs own all intellectual property rights resulting from the project, but R\&D performers may benefit from preferential use of the outcomes.

9 Participants of the Cooperation program rely much more on networking and outsourcing of research activities to RTDI performers in order to meet their innovation needs, since they have no or little in-house R\&D capacity. 
of the Eurostars Joint Program is a central and national management, which enables clear and transparent organization and timely accomplishment. SMEs participating in Eurostars are fast-growing SMEs with high R\&D intensity: 40 percent are micro SMEs ( $0-9$ employees) with very high impact expectations and 43 percent are small SMEs (10-49 employees) with high impact expectations. To a large extent, Eurostars attracts participants in high-tech sectors with highgrowth potential, such as ICT and biotech.

Although in past FPs, the participation from industry was lower than from universities (whether related to the share of funding or to the number of participants) (European Parliament, 2013), in the period from 2007 to 2013, SMEs accounted for 18.5 percent of the Framework Program participants. The findings of the interim report on the performance of SMEs within FP7 (European Commission, 2014) show that the effects that are considered to be most economically significant are those related to the creation of new knowledge. Namely, more than 90 percent of the SMEs interviewed stated that they managed to gain new knowledge and/or know-how. As for cooperation aspects, 81 percent of the SMEs interviewed established new strategic relationships with partners abroad, while 57 percent managed to launch follow-up projects with their (newly found) partners and 61 percent claimed to have gained access to research networks they did not have before. Finally, with regard to actual commercialization, 81 percent of the SMEs claimed to have advanced their products using the project results and 71 percent managed to implement an innovation based on the project. Thus, the majority of SMEs reported positive impacts on their competitiveness and other economic effects such as employment, turnover, and profitability. According to the European Commission study (2014), the SME Instrument program will be crucial in the further process, with the main goals of filling the gaps in funding for early-stage, high-risk research and innovation by SMEs, as well as stimulating breakthrough innovation.

In order to measure the effect of public funding on $R \& D$ input, several econometric models have been proposed, since estimating the effect of public 
subsidies is not that straightforward (Czarnitzki \& Delanote, 2015). Most of the studies so far have investigated the effect of public policy on R\&D intensity, referred to as input additionality (the effect of support measures on private R\&D expenditures). In addition to input additionality, output additionality refers to the impact of subsidies on firm performance (innovative sales, productivity, growth in turnover and/or employment, profitability), and behavioral additionality refers to changes in firms' innovative behavior induced by public support measures (Radicic, Pugh, Hollanders, Wintjes, \& Fairburn, 2016). Among micro-level studies, a number of papers use the CIS surveys, which, among the questions regarding the characteristics of businesses and their innovation activities, ask firms if they have received any public financial support for their innovation activities.

Catozzella and Vivarelli (2011), by analyzing the Italian CIS3 dataset, estimate the impact of public funding on innovative productivity measured as the ratio of innovative sales to innovative expenditures. The model is estimated using a bivariate endogenous switching model, which yields an average treatment on the treated (ATT) effect of -4.95 percentage points. Garcia and Mohnen (2010) explore the impact of public funding on $\mathrm{R} \& \mathrm{D}$ intensity as well as innovation output in Austrian firms using the CIS3 dataset. Their results vary depending on the source of funding and show that EU support has no effect on either innovation input or innovation output. However, central government support has a positive effect on both categories of product innovation, by increasing innovative sales of new-to-firm product innovations by 2.5 percentage points and by increasing innovative sales of new-to-market product innovations by 3.4 percentage points. On the other hand, research done by Czarnitzki and LopesBento (2013) implies that EU grants (relative to national ones) result in higher effects on private $\mathrm{R} \& \mathrm{D}$.

Blažkova (2016) evaluates the impacts of project support for research, development, and innovations on the economic performance of small and medium-sized enterprises in the region of South Moravia in the Czech Republic. 
The results point to a direct positive relationship between the amount of public funding and the profitability in SMEs. Almus and Czarnitzki (2003), using a non-parametric matching approach, analyze the effects of public R\&D policy schemes on the innovation activities of firms in Eastern Germany. The results show that firms increased their innovation activities by about 4 percentage points in comparison to cases where no public financial means were provided. Becker (2015), on a sample of 15 EU countries, analyzes whether publicly funded innovative activities foster the competitiveness of the companies, proxied by labor productivity (measured by turnover per employee), as well as the employment and turnover in the period between 2006 and 2008. The results point to a positive influence of public innovation support on labor productivity, a negative influence on turnover, and a negative but not significant influence on employment. The effects of these factors are very weak, whereas other coefficients (such as the money spent on innovative activities) clearly show positive effects for all three indicators. All of the evaluations made so far yield ambiguous results. Nonetheless, whether negative or positive, the output effects are small (Radicic et al., 2016).

One of the main issues often highlighted in research is whether EU R\&D funds are additional to $R \& D$ financed by firms (i.e. do they crowd-in private $R \& D$ investments) or whether they represent a substitute (i.e. crowd-out) for private R\&D. Namely, there is a large body of literature shifting away from the view that public funding often crowds-out private R\&D to evidence that funding stimulates private R\&D (Hussinger, 2008; Duguet, 2006; Cerulli \& Potì, 2012 , etc.). Generally, the complementarity between two or more variables can be tested by checking whether the demand for one increases in the presence of the other one (at least in the case of two variables). However, empirical results on this issue are mixed, especially for SMEs. For example, one strand of research shows that the crowding-in effect is stronger for small and young firms (ZunigaVicente, Alonso-Borego, Forcadell, \& Galan, 2014). Also, Lach (2002) finds that the effect of grants differs between small and large firms, implying that 
R\&D effects of the factors under consideration are not homogeneous across the cross-section dimension of firms, industries, or countries (Becker, 2015). ZunigaVicente et al. (2014) conclude that the empirical evidence is mixed, which can be attributed to differences in the populations under study (time periods, countries of interest, business sectors), the variables used, and the empirical approach.

Finally, although it has been confirmed that participation of SMEs in EU programs can have significant positive effects on some aspects of innovation performance, the final effects will depend also on the SMEs' capability to take advantage of internal factors (such as R\&D, capital investments, quality of skills, knowledge of the market, etc.). This implies that such participation has more of an indirect than direct effect on economic performance (Norman \& Klofsten, 2010). Barajas et al. (2011) analyze whether research joint ventures have a positive impact on SME performance. Concretely, they quantify the impact of SME-specific measures financed by FP6 on the performance of SMEs in Spain, considering two dimensions (technological outputs and economic results). Specifically, in a first step they analyze how the participation of an SME in an FP project affects its generation of new knowledge, which is approached by intangible fixed assets as an indirect measure of innovation output, since the knowledge generated in the $R \& D$ project will usually be reflected by the volume of intangibles inside the firm. In a second step, using the alternative measures of economic results as dependent variables-EBITDA, sales, and labor productivity-the authors analyze whether the participation also has a significant impact on these three economic performance indicators. The results show that if SMEs are cooperative, this increases the ratio of intangible fixed assets over employment by almost 55 percent, confirming the positive effect on technological performance. In addition, regardless of the dependent variable on economic performance, the FP participation is not statistically significant, implying that technological cooperation within the FP does not have a direct effect on performance. However, the impact of the predicted value of "intangible fixed assets per employee" (or "intangible fixed assets") on economic performance is statistically significant, 
reflecting an indirect effect of innovative SMEs' cooperation on economic performance. Finally, since the effects are significant three years after the end of the project, the authors conclude that SMEs participating in the FP have shorterterm objectives than large firms.

The other recent study by De Prato, Nepelski, and Pirolli (2015) documents that SMEs that participate in ICT FP7/CIP projects deliver a substantial number of innovations, showing that participation in such projects is beneficial for advancing innovation and commercialization activities. The study finds that on average there are nearly two new or substantially improved products or services delivered within each ICT FP7/CIP project. Also, about 41 percent of all organizations behind high-potential innovators are SMEs, although they represent only 14 percent of total EC funding and 16 percent of total program participants. Several other empirical studies (European Commission, 2014, 2015) that focus on surveying and measuring the impact on progress in innovation activities of enterprises participating in EU-supported R\&D programs such as FP7, also show similar results and point to a beneficial impact on innovation output.

\section{Horizon 2020 Support to SME R\&l}

In order to ensure stronger involvement of SMEs in gaining EU R\&I funding in the period between 2014 and 2020, the Horizon 2020 program was launched at the end of 2013. Within it, a new integrated and dedicated SME instrument was created to address the specific needs of SMEs, which were encouraged to participate across the entire program. Horizon 2020 currently brings together all previously existing EU modes of research and innovation funding (including the Framework Program and the innovation-related activities of the CIP Program and the European Institute of Innovation and Technology), and is the key tool in implementing the Innovation Union flagship initiative (European Parliament, 2013). Further, it has also included programs such as Enterprise Europe Network and Eurostars that provide help to SMEs in accessing market information, 
finding potential business and technology partners to participate in EU projects, and exploring the benefits that come with international R\&D collaboration.

The European Commission document "State of the Innovation Union 2015" states: "The SME Instrument is designed to develop, grow and internationalize highly innovative SMEs, regardless of whether they are high-tech and researchdriven, or social or services companies whose innovations are not based on research. It is expected that this integrated approach, together with simplification efforts, will lead to at least 20 percent from the total combined budgets of the 'Leadership in Enabling and Industrial Technologies' (LEIT) and the 'Societal Challenges' components of Horizon 2020 being allocated to SMEs over the 2014-2020 duration of Horizon 2020 as well as additional 7 percent through SME Instrument" (European Commission, 2015, p. 33). Table 3 brings a specification of available support to SMEs in H2020 and assigned budgets.

Table 3: Envisaged H2020 Support to the SME Sector, with Assigned Budgets and Policy Targets

\begin{tabular}{|c|c|}
\hline Instrument & SME participation target \\
\hline $\begin{array}{l}\text { H2020 Collaborative Projects (i.e. transnational } \\
\text { consortia of minimum } 3 \text { partners) }\end{array}$ & $\begin{array}{l}\text { SMEs to account for } 20 \text { percent of the budget in } \\
\text { Industrial Leadership and Societal Challenges. } \\
\text { Approximately EUR } 6 \text { billion until } 2020 \text {. }\end{array}$ \\
\hline $\begin{array}{l}\text { SME Instrument (Technology Readiness project } \\
\text { for level higher than } 6 \text { ) }\end{array}$ & $\begin{array}{l}7 \text { percent of the combined budget for } \\
\text { Industrial Leadership and Societal Challenges. } \\
\text { Approximately EUR } 3 \text { billion. }\end{array}$ \\
\hline $\begin{array}{l}\text { Eurostars (transnational projects, co-financing of } \\
50 \text { percent) }\end{array}$ & $\begin{array}{l}\text { EU contribution set at EUR } 287 \text { million and } \\
\text { participatory country contributions set at EUR } \\
861 \text { million. This budget is significantly larger } \\
\text { than the first Eurostars Joint Program budget. }\end{array}$ \\
\hline $\begin{array}{l}\text { Access to Finance (reserved for RDI-driven- } \\
\text { SMEs and midcaps) }\end{array}$ & Guarantees and equity up to EUR 900 million. \\
\hline
\end{tabular}

Source: European Commission (2017a).

Available data on the absorption of the H2020 program budgets dedicated to SMEs speak of success of their increased participation in the 2014-2017 period and overall satisfactory progress in specific SME participation target achievements. According to the Horizon 2020 Interim Evaluation Report 
(European Commission, 2017a), by January 2017, SMEs accounted for 23.9 percent of the $\mathrm{H} 2020$ budget $^{10}$ (approximately EUR 3.5 billion out of the available EUR 6 billion) allocated to the Societal Challenges and LEIT programs. This share indicates that the policy plans of increased SME participation in approved grant funding are being fulfilled, at least in the first half of the Horizon 2020 implementation. The number of supported projects SMEs participated in was even higher: 26.9 percent. It is expected that this combined budget of EUR 6 billion will be invested into Europe's most innovative SMEs through collaborative consortia grants by the end of 2020 .

Several very detailed background studies for the interim evaluation of Horizon 2020 and the impact of its funding on SMEs have found EU value added on the performance of SMEs, which would not be possible if SMEs relied solely on private or national funding. ${ }^{11}$

In order to bridge the gap between innovation ideas and efforts towards producing close-to-market products and services, the Fast Track Innovation (FTI) pilot program was introduced in 2015 within the LEIT and Societal Challenges budgets to promote innovations by industry-intensive consortia of 3-6 members. In the 2015-2016 period, the program had a very positive response from industry, resulting in 75 funded projects with EC contribution of EUR 161.2 million. Out of the 342 selected entities, 73 percent were SMEs (European Commission, 2017a).

Increased R\&I investments of SME recipients of H2020 funded projects in the 2014-2017 period have resulted in tangible and measurable innovation outputs such as patents, trademarks, or other forms of IPR output. ${ }^{12}$ According to the H2020 Interim Evaluation (European Commission, 2017c), which examined key performance indicators by January $2017^{13}$, there were in total 153 patent

\footnotetext{
10 For comparison, average participation of SMEs in the FP7 budget was about 15 percent.

11 See, for instance, European Commission (2017f).

12 It should be noted that these data are extracted by the EC based on the projects' self-reporting data.

13 eCORDA data with cut-off date January 1, 2017.
} 
applications and 34 patents awarded, along with 24 trademark applications that were all awarded. Two-thirds of these results derive from Phase 1 and 2 of the SME Instrument program. However, these are only preliminary figures as most of the projects are on-going and only about 10 percent of the funded projects are completed.

When analyzing the data on total H2020 budget allocations to SMEs in the 2014-2017 period (by EU member countries, expressed in logs) on one side, and data on the summary innovation index as a proxy for the general innovation performance indicator ${ }^{14}$ (also in logs) on the other side, one can conclude that countries that received a larger amount of EU funds score better when it comes to measuring innovation performance through the European Innovation Scoreboard (Figure 4) $)^{15}$.

Figure 4: H2020 Budget Allocations to SMEs and Innovation Performance of EU Member States Measured by European Innovation Scoreboard

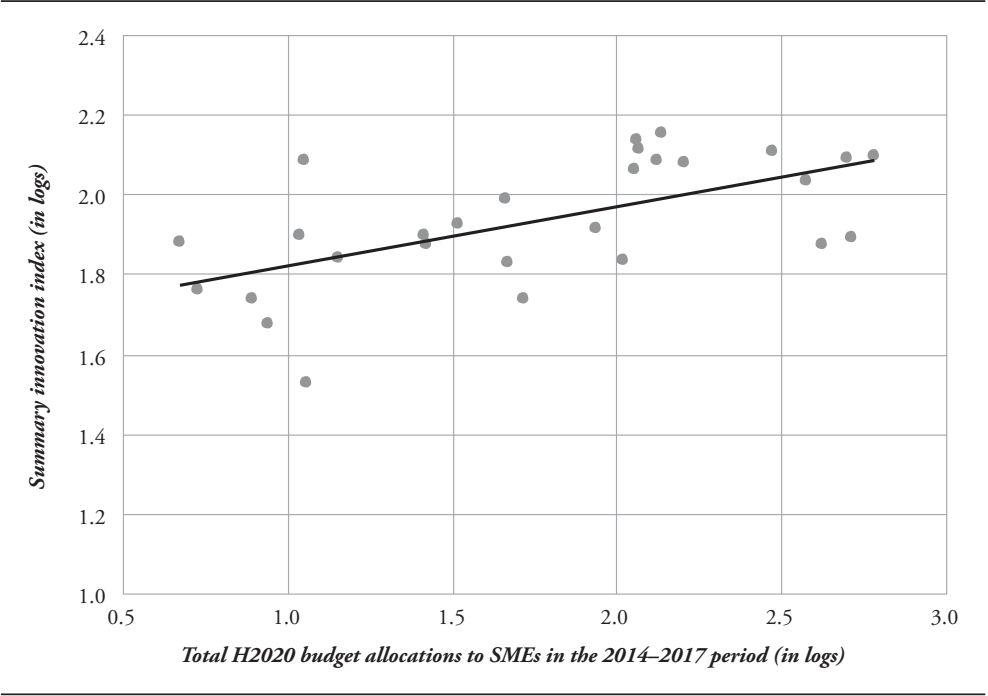

Sources: Authors' calculation based on eCORDA, self-reported data by the SME project beneficiaries, with cut-off date June 2017, and European Innovation Scoreboard 2017 (European Commission, 2017d).

14 European Innovation Scoreboard 2017 (European Commission, 2017d).

15 The calculated coefficient of correlation amounts to 0.60 . 
The SME Instrument program ${ }^{16}$ especially supports market-creating innovations in single SMEs with high growth potential and ambition to become global leaders. It represents quite a unique attempt to invest public funds into highly risky and disruptive innovations in SMEs (European Commission, 2017e). This type of investment has proved to be rather attractive to well-performing single SMEs with potentially new-to-market innovations, as it offers direct and equity-free funding. The funding criteria very much underline the prospect of commercializing the high-risk innovations and outperforming competitors. Most funding from the SME Instrument program in the 2014-2016 period went to new-to-market innovations in the areas of medicine and healthcare (412 SMEs), clean technology (271 SMEs), and energy (239 SMEs), while the area of ICT (open and disruptive innovation) is the most transversal topic across all sectors. By the end of Horizon 2020, the SME Instrument program will have supported some 7,500 SMEs in getting their innovations delivered to the market. ${ }^{17}$

\section{Conclusions}

A constant matter of concern for EU policy makers is how to monitor and measure progress of the available EU funding and its impacts on recipients from the real sector, particularly SMEs. Namely, it is SMEs that are chiefly targeted with numerous concrete efforts to incentivize their innovation and performance.

From the policy perspective, the examined empirical evidence in this paper suggests positive effects of participating in EU-funded programs on incentivizing innovation activities, output, and business performance of SMEs. The results of a number of surveyed empirical studies ${ }^{18}$ demonstrate that SMEs that

16 A specific part of the H2020 program aimed at SME-tailored support to stimulate all forms of innovation in SMEs, targeting especially those with high potential to grow and internationalize (European Commission, 2017e).

17 More details on the dedicated SME instrument within Horizon 2020 are available at: http://ec.europa.eu/ programmes/horizon2020/en/h2020-section/sme-instrument.

18 Surveyed by the authors for the Literature Review section of the Horizon 2020 project "Investigating the Impact of the Innovation Union - I3U” (Grant Agreement No. 645884). 
participate in EU-funded projects deliver a substantial number of innovations, showing that participation in such projects is beneficial for advancing innovation and commercialization activities, as well as for technological and economic performance and efficiency (see, for instance, Becker, 2015). Thus, based on the analyzed results of previous research studies, we could expect future positive impacts of increased availability of EU funding through Horizon 2020 on SME innovation performance. However, the complex quantification of scale of such a positive impact on SME performance, measured by productivity and employment growth, will depend not only on firm size, age, and industry competitiveness conditions, but also very much on whether the SMEs invest more into product or process innovations.

Regarding the practical implications of the reviewed research, although there have now been almost 50 years of systemic efforts in developing innovation indicators, measuring innovation and how much it contributes to boosting economic growth, productivity, and new employment still presents an important methodological challenge for researchers around the world (OECD, 2010). It is especially difficult to measure and assess how innovation is, or could be, linked to a specific policy or institutional context. In those terms, a lot remains to be done regarding the measurement challenges that statisticians, researchers, and policy makers need to address to precisely capture the contribution and impact of innovation activities - both on the economy as a whole, and on the performance and competitiveness of firms. The net effects of public, and especially EU funding, on firm-level R\&D and innovation (i.e. additionality stemming from various funding sources and their impact on productivity and employment growth) are in general very difficult to quantify precisely. They depend on a multitude of factors on the firm and industry level, and different empirical studies have not come to a conclusive answer on this research task, especially when it comes to determining the causality of impacts, as the Zuniga-Vincente et al. (2014) extensive literature survey clearly demonstrates. 
Future research avenues worth exploring are related to finding answers to the methodological issues of measuring innovation impacts. The continuous challenges of data availability and their quality that are emphasized in many analyses, including our own, require access to longitudinal, historical, and open quantitative microdata to ensure better monitoring, measurement, and evaluation of the downstream impacts of EU funding. Without such longitudinal and historical data, we cannot measure with adequate preciseness the short- versus long-run effects of EU R\&D programs and determine the ultimate effectiveness of such interventions, nor the causality of impacts they produce at the firm level. These microdata would also better reveal how the effects of EU funding have been distributed over time, as there is an evident time-lag between the time when funding was received and the time when it yielded additional innovations in recipient SMEs. These requests seem essential for proper evidence-based impact assessment and control of the achievements of the EU 2020 strategy and Innovation Union commitments, and thus could be relevant for EU policy makers. With regard to improving qualitative data analysis, this would especially entail developing indicators that would better document significant organizational, behavioral, and sectorial differences among recipient innovative SMEs, especially fast-growing young firms. 


\section{Literature}

Afcha, S. (2012). Analysing the interaction between R\&D subsidies and firm's innovation strategy. Journal of Technology Management \& Innovation, 7(3), 5870. doi: https://doi.org/10.4067/S0718-27242012000300006

Almus, M., \& Czarnitzki, D. (2003). The effects of public R\&D subsidies on firms' innovation activities: The case of Eastern Germany. Journal of Business and Economic Statistics, 21(2), 226-236. doi: https://doi.org/10.1198/073500103288618918

Barajas, A., Huergo, E., \& Moreno, L. (2011, October). The impact of research joint ventures on SMEs performance: Empirical evidence for Spanish firms. Paper presented at the conference The Dynamics of Europe's Industrial Structure and the Growth of Innovative Firms, Seville, Spain.

Becker, B. (2015). Public R\&D policies and private R\&D investment: A survey of the empirical evidence. Journal of Economic Surveys, 29(5), 917-942. doi: https://doi.org/10.1111/joes.12074

Blažkova, I. (2016). The impact of public support for $R \& D$ on the economic performance of SMEs. Acta Universitatis, 64(1), 213-222. doi: https://doi. org/10.11118/actaun201664010213

Canepa, A., \& Stoneman, P. (2008). Financial constraints to innovation in the UK: Evidence from CIS2 and CIS3. Oxford Economic Papers, 60(4), 711-730. doi: https://doi.org/10.1093/oep/gpm044

Catozzella, A., \& Vivarelli, M. (2011). Assessing the impact of public support on innovative productivity, DISCE Working Paper No. 77. Milano: Universita Catolica de Sacro Cuore.

Cerulli, G., \& Potì, B. (2012). The differential impact of privately and publicly funded R\&D on R\&D investment and innovation: The Italian case. Prometheus, 30(1), 113-149. doi: https://doi.org/10.1080/08109028.2012.671288

Czarnitzki, D., \& Delanote, J. (2015). R\&D policies for young SMEs: Input and output effects, ZEW Discussion Paper No. 15-032. 
Czarnitzki, D., \& Lopes-Bento, C. (2013). Value for money? New microeconometric evidence on public R\&D grants in Flanders. Research Policy, 42(1), 76-89. doi: https://doi.org/10.1016/j.respol.2012.04.008

Damijan, J., Kostevc, C., \& Stare, M. (2014). Impact of innovation on employment and skill upgrading, SIMPATIC 7th EU Project, Working Paper No. 7.

David, P., Hall, B., \& Toole, A. (2000). Is public R\&D a complement or substitute for private R\&D? A review of the econometric evidence. Research Policy, 29(4-5), 497-529. doi: https://doi.org/10.1016/S0048-7333(99)00087-6

De Prato, G., Nepelski, D., \& Pirolli, G. (2015). Innovation radar: Identifying innovations and innovators with high potential in ICT FP7, CIP \& Horizon 2020 projects (JRC Science and Policy Report EUR 27314 EN). Seville: JRC-IPTS.

Duguet, E. (2006). Innovation height, spillovers and TFP growth at the firm level: Evidence from French manufacturing. Economics of Innovation and New Technology, 15(4-5), 415-442. doi: https://doi.org/10.1080/10438590500512968

European Commission. (2010a). Europe 2020: A European strategy for smart, sustainable and inclusive growth [COM (2010) 2020]. Brussels: European Commission.

European Commission. (2010b). Innovation Union. Retrieved from: http:// ec.europa.eu/research/innovation-union/index.cfm

European Commission. (2011). Policies in support of high-growth innovative SMEs (INNO-Grips Policy Brief No. 2). Retrieved from: http://innogrips.empirica. biz/fileadmin/innogrips/documents/01_policy\%20briefs/ig_policybrief_2_highgrowth_smes.pdf

European Commission. (2014). Performance of SMEs within FP7: An interim evaluation of FP7 components (Volume 1, Main Report). Retrieved from: https:// www.kmuforschung.ac.at/wp-content/uploads/2018/01/Volume-I-SMEs-inFP7-Final-May-2014-EC-Format.pdf 
European Commission. (2015). State of the Innovation Union 2015. Retrieved from: http://ec.europa.eu/research/innovation-union/pdf/state-of-the-union/ 2015/state_of_the_innovation_union_report_2015.pdf

European Commission. (2017a). Horizon 2020 interim evaluation report: Annex 1 [SWD (2017) 221 final]. Retrieved from: http://ec.europa.eu/research/ evaluations/pdf/archive/h2020_evaluations/swd(2017)221-annex-1-interim_ evaluation-h2020.pdf

European Commission. (2017b). Horizon 2020 interim evaluation report: Annex 2 [SWD(2017) 220 and 222 final]. Retrieved from: https://ec.europa.eu/research/ evaluations/pdf/archive/h2020_evaluations/swd(2017)221-annex-2-interim_ evaluation-h2020.pdf

European Commission. (2017c). In-depth interim evaluation of Horizon 2020 [Commission Staff Working Document, SWD Final 220, version updated on June 13, 2017]. Retrieved from: https://ec.europa.eu/research/evaluations/pdf/ archive/h2020_evaluations/swd(2017)220-in-depth-interim_evaluation-h2020. pdf

European Commission. (2017d). European Innovation Scoreboard 2017. Retrieved from: https://ec.europa.eu/docsroom/documents/24829

European Commission. (2017e). Accelerating innovation in Europe: Horizon 2020 SME Instrument impact report (2017 edition). Retrieved from: https:// ec.europa.eu/easme/sites/easme-site/files/accelerating_innovation_in_europe_ horizon_2020_smei_impact_report.pdf

European Commission. (2017f). Assessment of the Union added value and the economic impact of the EU Framework Programmes (PPMI Final Report). Retrieved from: http://ec.europa.eu/research/evaluations/pdf/archive/other_ reports_studies_and_documents/assessment_of_the_union_added_value_and_ the_economic_impact_of_the_eu_framework_programmes.pdf

European Commission. (2017g). Interim evaluation of the Eurostars-2 Joint Programme. Retrieved from: https://ec.europa.eu/research/evaluations/pdf/ report_interim_evaluation_eurostars2_051011.pdf 
European Commission. (2018). European Innovation Scoreboard 2018. Retrieved from: https://ec.europa.eu/docsroom/documents/30281

European Innovation Scoreboard 2018. European Innovation Scoreboard 2018 database. Retrieved from: http://159.122.11.36/f/extensions/a1/a1.html

European Parliament. (2013). SMEs participation under Horizon 2020. Retrieved from: https://publications.europa.eu/en/publication-detail/-/ publication/06dc42c5-e262-4768-a3e0-c0a94af7e4e1

Eurostat. CIS innovation statistics explained. Retrieved from: https://ec.europa. eu/eurostat/statistics-explained/index.php/Glossary:Community_innovation_ survey_(CIS)

Eurostat. Community innovation survey 2012 (CIS 2012). Retrieved from: https:// ec.europa.eu/eurostat/web/science-technology-innovation/data/database

Eurostat. Community innovation survey 2014 (CIS 2014). Retrieved from: https:// ec.europa.eu/eurostat/web/science-technology-innovation/data/database

Eurostat. Innovation statistics, 2017. Retrieved from: https:/ec.europa.eu/ eurostat/statistics-explained/index.php/Innovation_statistics

Eurostat. Provisional CIS 2016. Retrieved from: http://159.122.11.36/f/ extensions/a1/a1.html

Eurostat. (2014). Patent statistics at Eurostat: Mapping the contribution of SMEs in EU patenting. Retrieved from: https://ec.europa.eu/eurostat/web/productsmanuals-and-guidelines/-/KS-GQ-14-009?inheritRedirect=true

Garcia, A., \& Mohnen, P. (2010). Impact of government support on R\&D and innovation, UNU-MERIT Working Paper Series No. 034. Maastricht: UNUMERIT, Maastricht Economic and Social Research and Training Centre on Innovation and Technology.

Guellec, D., \& von Pottelsberghe, B. (2003). The impact of public R\&D expenditure on business R\&D. Economics of Innovation and New Technology, 12(3), 225-244. doi: https://doi.org/10.1080/10438590290004555 
Hall, B. (2011). Innovation and productivity, NBER Working Paper No. 17178. Retrieved from: http://www.nber.org/papers/w17178.pdf

Hall, B., \& Lerner, J. (2010). The financing of R\&D and innovation. In B. Hall, $\&$ N. Rosenberg (Eds.), Handbook of the economics of innovation (Vol. 1, pp. 609-639). Amsterdam: Elsevier. Retrieved from: https://www.sciencedirect.com/ handbook/handbook-of-the-economics-of-innovation/vol/1/suppl/C

Hussinger, K. (2008). R\&D and subsidies at the firm level: An application of parametric and semiparametric two-step selection models. Journal of Applied Econometrics, 23(6), 729-747. doi: https://doi.org/10.1002/jae.1016

Keizer, J. A., Dijkstra, L., \& Halman, J. M. (2002). Explaining innovative efforts of SMEs: An exploratory survey among SMEs in the mechanical and electrical engineering sector in the Netherlands. Technovation, 22(1), 1-13. doi: https:// doi.org/10.1016/S0166-4972(00)00091-2

Lach, S. (2002). Do R\&D subsidies stimulate or displace private R\&D? Evidence from Israel. The Journal of Industrial Economics, 50(4), 369-390. doi: https://doi. org/10.1111/1467-6451.00182

Love, J., \& Roper, S. (2015). SME innovation, exporting and growth: A review of existing evidence. International Small Business Journal, 33(1), 28-48. doi: https:// doi.org/10.1177/0266242614550190

Mazzucato, M. (2013). The entrepreneurial state: Debunking public vs. private sector myths. London and New York, NY: Anthem Press.

Norman, C., \& Klofsten, M. (2010). Financing new ventures: Attitudes towards public innovation support. In R. Oakey, A. Groen, P. van der Sijde, \& G. Cook (Eds.), New technology-based firms in the new millennium (Volume 8, pp. 89110). Bingley: Emerald Group Publishing. doi: https://doi.org/10.1108/S18760228(2010)0000008009

OECD. (2010). SMEs, entrepreneurship and innovation. Paris: OECD Publishing. doi: https://doi.org/10.1787/9789264080355-en 
Peters, B., Dachs, B., Dünser, M., Hud, M., Köhler, C., \& Rammer, C. (2014). Firm growth, innovation and the business cycle: Background report for the 2014 competitiveness report (Series ZEW Expertises No. 110577). Mannheim: Zentrum für Europäische Wirtschaftsforschung (ZEW).

Radas, S., Anic, D., Tafro, A., \& Wagner, V. (2015). The effects of public support schemes on small and medium enterprises. Technovation, 38(2), 15-30. doi: https://doi.org/10.1016/j.technovation.2014.08.002

Radicic, D., Pugh, G., Hollanders, H., Wintjes, R., \& Fairburn, J. (2016). The impact of innovation support programs on small and medium enterprises innovation in traditional manufacturing industries: An evaluation for seven European Union regions. Environment and Planning C: Politics and Space, 34(8), 1425-1452. doi: https://doi.org/10.1177/0263774X15621759

Rodrik, D. (2015, January 14). From welfare state to innovation state. Project Syndicate. Retrieved from: http://www.project-syndicate.org/commentary/laborsaving-technology-by-dani-rodrik-2015-01

Stam, E., \& Wennberg, K. (2009). The roles of R\&D in new firm growth. Small Business Economics, 33(1), 77-89. doi: https://doi.org/10.1007/s11187-0099183-9

Veugelers, R. (2008). The role of SMEs in innovation of the EU: A case for policy intervention? Review of Business and Economics, 53(3), 239-262.

Wessner, C. (Ed.). (2008). An assessment of the Small Business Innovation Research program. Washington, DC: National Academy of Sciences.

Zuniga-Vincente, J. A., Alonso-Borego, C., Forcadell, F. J., \& Galan, J. I. (2014). Assessing the effect of public subsidies on firm $\mathrm{R} \& \mathrm{D}$ investment: A survey. Journal of Economic Surveys, 28(1), 36-67. doi: https://doi.org/10.1111/j.14676419.2012.00738.x 